\title{
Evidence for two pulses of glaciation during the late Proterozoic in northern Utah and southeastern Idaho
}

\author{
MAX D. CRITTENDEN, Jr.* U.S. Geological Survey, Menlo Park, California 94025 \\ NICHOLAS CHRISTIE-BLICK Exxon Production Research Co., P.O. Box 2189, Houston, Texas 7700I \\ PAUL KARL LINK Department of Geology, Idaho State University, Pocatello, Idaho 83029
}

\section{ABSTRACT}

A record of glaciation during late Proterozoic time is preserved in a number of localities extending from the Sheeprock Mountains, Utah, to Pocatello, Idaho, and from the Park City area $40 \mathrm{~km}$ east of Salt Lake City to the Deep Creek Range along the Utah-Nevada line. Over much of this area, the glacial deposits and associated rocks thicken westward and form the basal part of a miogeoclinal wedge that accumulated near the late Proterozoic and early Paleozoic continental margin. In the east, such deposits are thin and rest on Archean basement or rocks of Proterozoic Y age; in the west, they are part of thicker sequences in which deposition apparently continued without significant interruption from late Proterozoic into Cambrian time. In many places, the original continuity between the western and eastern parts of the depositional wedge has been obscured by thrusting of Cretaceous and early Tertiary age that carried the thick basinal sequences eastward over those deposited on the continental platform. Recent mapping of Fremont Island in Great Salt Lake, the Wasatch Range between Ogden and Brigham City, and the Sheeprock Mountains shows that glacial episodes represented either by diamictite or by dropstones enclosed in finegrained laminated beds are separated by as much as $1,000 \mathrm{~m}$ of non-glacial deposits, including black slate, alternating graywacke and siltstone, quartzite, and conglomerate. Using reasonable sedimentation rates for such deposits and by comparison with modern analogues, we infer that two episodes of glaciation, each probably consisting of multiple advances and retreats, were separated by a non-glacial interval of a few hundred thousand to a few million years' duration.

\footnotetext{
*Deceased, November 1982.
}

Correlation of the allochthonous, miogeoclinal glacial deposits with the single glacial unit present in autochthonous and parautochthonous platform sites is uncertain, but our interpretation of sedimentary facies and paleogeography suggests that only the younger of the two episodes recorded in the allochthon is represented by the diamictites of the autochthon.

\section{INTRODUCTION}

Since Hintze (1913) and Blackwelder (1910, 1925, 1932) first described them, the distinctive boulder-bearing black diamictites of northern Utah and southeastern Idaho have been ascribed alternately to glacial (Calkins and Butler, 1943; Crittenden and others, 1952) and non-glacial processes (Condie, 1967; Schermerhorn, 1974). The most recent studies by Varney (1976), Blick (1979), and Ojakangas and Matsch (1980) have provided definitive evidence of glacial activity in the form of striated and faceted clasts, dropstones, isolated sand and gravel clots, and a striated glacial pavement. Although interpretations differ as to the details of paleogeographic setting and depositional mechanisms, most authors now agree that much of the diamictite was deposited in a glaciomarine environment. Similar rocks constitute the earliest deposits of the late Proterozoic and early Paleozoic miogeocline in many parts of the Cordillera (Crittenden and others, 1972; Stewart, 1972; Christie-Blick and others, 1980).

The diamictites are present in many areas of northern Utah and southeastern Idaho (Fig. 1), and it was evident some time ago (Crittenden and others, 1971) that the distribution of these and overlying Paleozoic rocks has been modified by tectonic transport that took place during the development of the Cordilleran fold belt (King, 1969). As a result, the rocks exposed in eastern au- tochthonous structural settings (center right edge in Fig. 1) are parts of thin and locally deposited sequences in which multiple unconformities attest to interruptions of sedimentation, whereas most occurrences in the allochthon ( $\mathrm{A}$ in Fig. 1 ) are parts of thicker sequences in which deposition apparently continued without major tectonic disturbance into Cambrian time. In the autochchthon, glacial sediments' accumulated above thick trough deposits of Proterozoic $\mathrm{Y}$ age or were deposited directly on crystalline basement of Archean and early Proterozoic age. In the allochthon, similar and apparently correlative glacial deposits are intercalated with thick non-glacial sediments and locally with submarine volcanic rocks. In many areas, the base of these allochthonous sections either is not exposed or is cut out by thrusts, but locally these rocks unconformably overlie units of Proterozoic $X$ age not present within the autochthon.

In the autochthon, and in some areas of the Charleston-Nebo allochthon (in American Fork Canyon, for example) only one unit of glacially related rocks has been recognized, although there is evidence for repeated fluctuations of the ice margin during over-all retreat (Blick, 1979; ChristieBlick, 1980a). In several areas in the allochthon, however, two glacial episodes can be recognized, separated by a sufficient thickness of non-glacial deposits to suggest that the two episodes were separated by a time interval perhaps as long as the Pleistocene. This paper presents the evidence for

In this paper, "glacial sediments" are ones that accumulate in a glacial environment as defined by Boulton and Deynoux (1981). The term "nonglacial" is applied to sediments in which no glacial influence has been detected, even though some may have been derived by glacial activity or may have accumulated in an environment appreciably influenced by glacial meltwater. 


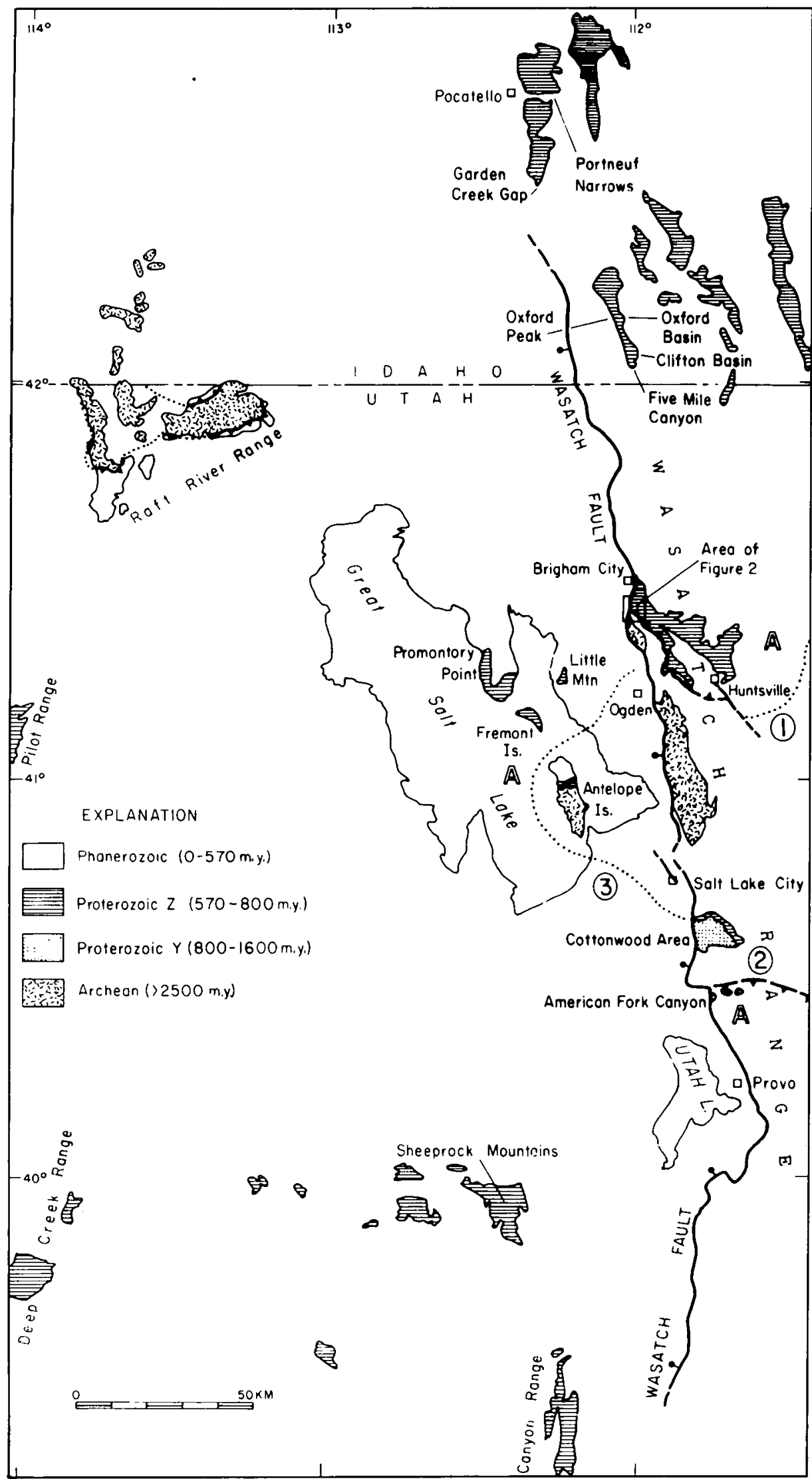

Figure 1. Map of northern Utah and southeastern Idaho showing extent of Precambrian rocks and localities referred to in text. (1) Willard-Paris thrust; (2) Charleston-Nebo thrust; (3) concealed trace of inferred connection between 1 and 2 ; (A) area of allochthon referred to in text.

this conclusion and assesses its significance for regional correlation of the upper Proterozoic rocks.

\section{GLACIAL RECORD IN THE AUTOCHTHON}

\section{Antelope Island}

Antelope Island (Fig. 1) is underlain mainly by granite gneiss inferred to be of Archean or early Proterozoic age (Bryant, 1980; Bryant and Graff, 1980; Hedge and others, 1983) and assigned to the Farmington Canyon Complex (Eardley and Hatch, 1940a). These crystalline rocks are overlain unconformably by little-metamorphosed rocks of Proterozoic $Z$ age, consisting of 45 $\mathrm{m}$ of diamictite, $40 \mathrm{~m}$ of pinkish-tanweathering laminated dolomite, and $35 \mathrm{~m}$ of argillite (only partly exposed). These units are in turn overlain disconformably by an indeterminate thickness, at least several tens of metres, of light tan to pale gray cobble and pebble conglomerate and quartzite, representing the basal part of the Tintic Quartzite (Cambrian). That coarse-grained quartzite was, we believe, correctly identified as Cambrian by Eardley and Hatch (1940b) but later was assigned to the Precambrian Mutual Formation by Larsen (1957), and this assignment was adopted for the geologic map of Utah by Stokes (1963). More recent comparisons with units exposed in the Wasatch Range in both he allochthon and autochthon confirm Eardley's identification as the Tintic Quartzite and emphasize a close relationship to the exposures in the Farmington-Bountiful section of the Wasatch Range (between Salt Lake City and Ogden) (Fig. 1), where the Tintic Quartzite rests directly on the Farmington Canyon Complex without any intervening rocks of Proterozoic $\mathrm{Z}$ age (Crittenden, 1972). These relations indicate that the line of zero thickness for Proterozoic $\mathrm{Z}$ rocks lies between Antelope Island 
and the Farmington-Bountiful section of the Wasatch.

The tectonic position of Antelope Island is uncertain. Rocks exposed there are structurally beneath the Willard thrust (Fig. 1; Crittenden, 1972), but they may be structurally above several thrusts that crop out in southwestern Wyoming (see Royse and others, 1975; Blick, 1979). We therefore regard Antelope Island as autochthonous or parautochthonous.

\section{Mineral Fork Area}

Glacial rocks older than the Cambrian Tintic Quartzite were recognized in the Cottonwood area (Fig. 1) by Hintze (1913) and by Calkins and Butler (1943) during mapping of the Alta and American Fork mining districts. Prior to 1952, the glacial units were called simply "tillite" and, because of the absence of clasts of the distinctive diamictite in the base of the overlying quartzite, were questionably assigned to the Cambrian (Calkins and Butler, 1943). Further mapping (Crittenden and others, 1952), however, showed that the diamictite, there named the Mineral Fork Tillite, was deposited above a major unconformity in two broad, shallow glacial valleys cut in the top of the older Big Cottonwood Formation and was overlapped unconformably by both the Mutual Formation (Proterozoic Z) and the basal conglomerate of the Tintic Quartzite (Early? and Middle Cambrian; see col. 9 of Fig. 4 below). These relations made it clear that the diamictite is separated from the overlying basal Cambrian strata by not merely one unconformity but two. Calkins's observation that clasts of diamictite are absent from the base of the Tintic Quartzite is now seen to be of no age significance.

The sedimentary environment of these glacial deposits (referred to as the Mineral Fork Formation by Christie-Blick) has been discussed most recently by Varney (1976), Ojakangas and Matsch (1980, 1982), Blick (1979), Christie-Blick (1980a, 1982a) and Knoll and others (1981). Evidence of glaciation includes a few dropstones, clots of sand or gravel enclosed in finer-grained strata perhaps analogous to those described by Ovenshine (1970), and striae on the underlying surface (Blick, 1979; Ojakangas and Matsch, 1980). There is considerable disagreement in detail about the interpretation of the Mineral Fork Tillite, but most recent workers agree that it accumulated at or near the margin of an ice sheet that reached the sea. Christie-Blick (1980a) cited evidence of repeated glacial fluctuations during over-all retreat but did not find evidence of prolonged periods of entirely non-glacial deposition. An obvious problem is that in the postulated glaciomarine environment the time interval represented by any particular hiatus is difficult to evaluate. The most that can be said is that there is no evidence that early glacial deposits within the Mineral Fork had consolidated sufficiently to yield clasts of diamictite to later glacial advances.

\section{GLACIAL RECORD IN THE ALLOCHTHON}

\section{Mouth of Perry Canyon}

In the northern Wasatch Range (Fig. 2), the upper plate of the Willard thrust is characterized by a thick sequence of littlemetamorphosed rocks of late Proterozoic age (Sorensen and Crittenden, 1976), apparently recognized by Blackwelder as early as 1910 (Blackwelder, 1910, 1932). Mapping prior to 1970 (Crittenden and others, 1971) showed that these sections, informally referred to as the Huntsville sequence, constitute a consistent set of formational units that are recognizable throughout western Utah and southeastern Idaho and that a diamictite-bearing unit occurs in the lower part of this sequence in most places where the base is exposed. More recent mapping (Sorensen and Crittenden, 1976) has shown that diamictite-bearing rocks, informally designated the "formation of Perry Canyon," are exposed almost continuously above the Willard thrust from the Wasatch front near Perry Canyon at least to Pineview Reservoir west of $\mathrm{H}$ untsville (Fig. 1), a distance of $25 \mathrm{~km}$. This mapping also showed that a higher strand of the thrust repeats both the diamictite-bearing units and the underlying Facer Formation. Inasmuch as the thrust descends stratigraphically westward, the thickest sections of both formations are exposed near the mountain front, where they are cut off by the Wasatch fault. Assuming that this descent continues, the rocks of the upper plate are presumed to have been deposited west of those of the lower plate, but the distance that originally separated them is uncertain; an estimate of 10 to $20 \mathrm{~km}$ appears reasonable on the basis of change in thickness of the Facer Formation and other evidence of the total trans- port on the Willard thrust (Crittenden, 1961; Blick, 1979).

The stratigraphically lowest and thickest section of the formation of Perry Canyon is in the upper plate of the Willard thrust, beginning just south of the mouth of Perry Canyon (Fig. 2), where the formation consists of three units. The lower and upper units are composed of diamictite and the intervening unit is interbedded graywacke and siltstone (see column 5 of Fig. 4 below). The lower diamictite, here about $365 \mathrm{~m}$ thick, rests directly on the Facer Formation. Its thickness is variable along strike, however; only $2 \mathrm{~km}$ to the east, it is a maximum of $60 \mathrm{~m}$ thick and is locally absent. Where diamicite is missing, the base of the Perry Canyon is marked by 1 to $5 \mathrm{~m}$ of coarse arkosic grit that grades upward into alternating graywacke and siltstone. Much of the lower diamictite appears massive, and some may be lodgement tillite (see Boulton and Deynoux, 1981), but intercalated lenses of siltstone 2 to $3 \mathrm{~m}$ thick indicate intermittent intervals of non-glacial deposition. Clasts are predominantly 5 to $10 \mathrm{~cm}$ in diameter, but a few are as large as $1 \mathrm{~m}$ and the largest observed is nearly $3 \mathrm{~m}$ long. A count of 100 clasts showed gneissic granite $(42 \%)$ and pale quartzite $(34 \%)$ to be the most abundant. Clasts of pale metarhyolite $(10 \%)$ are an unusual component seen only in this area; clasts of schist, basalt(?), dark quartzite, and carbonate rocks make up the remaining $14 \%$. Thin pods of badly altered metavolcanic rocks are present locally at the base of this lowest diamictite. At the top, it is overlain abruptly by graywacke and siltstone, although all of these rocks intertongue locally.

The medial part of the formation of Perry Canyon here consists of interbedded greenish-tan graywacke and dark gray to greenish-gray siltstone. Locally, thin lenses of laminated gray limestone are present at or just above the lower contact. On the ridge south of the mouth of Perry Canyon, lenticular beds of tan-weathering quartzitic graywacke or quartzitic sandstone attain a thickness of 1 to $2 \mathrm{~m}$. To the southeast, the medial unit forms much of the ridge crest between Willard and Perry Canyons. In this area, the dominant lithology is dark gray-to olive-drab-weathering siltstone in which even parallel bedding 3 to $5 \mathrm{~cm}$ thick combines with weak foliation, intersecting at an angle of $30^{\circ}$ to $40^{\circ}$, to produce a distinctively banded phyllite. Although poorly 


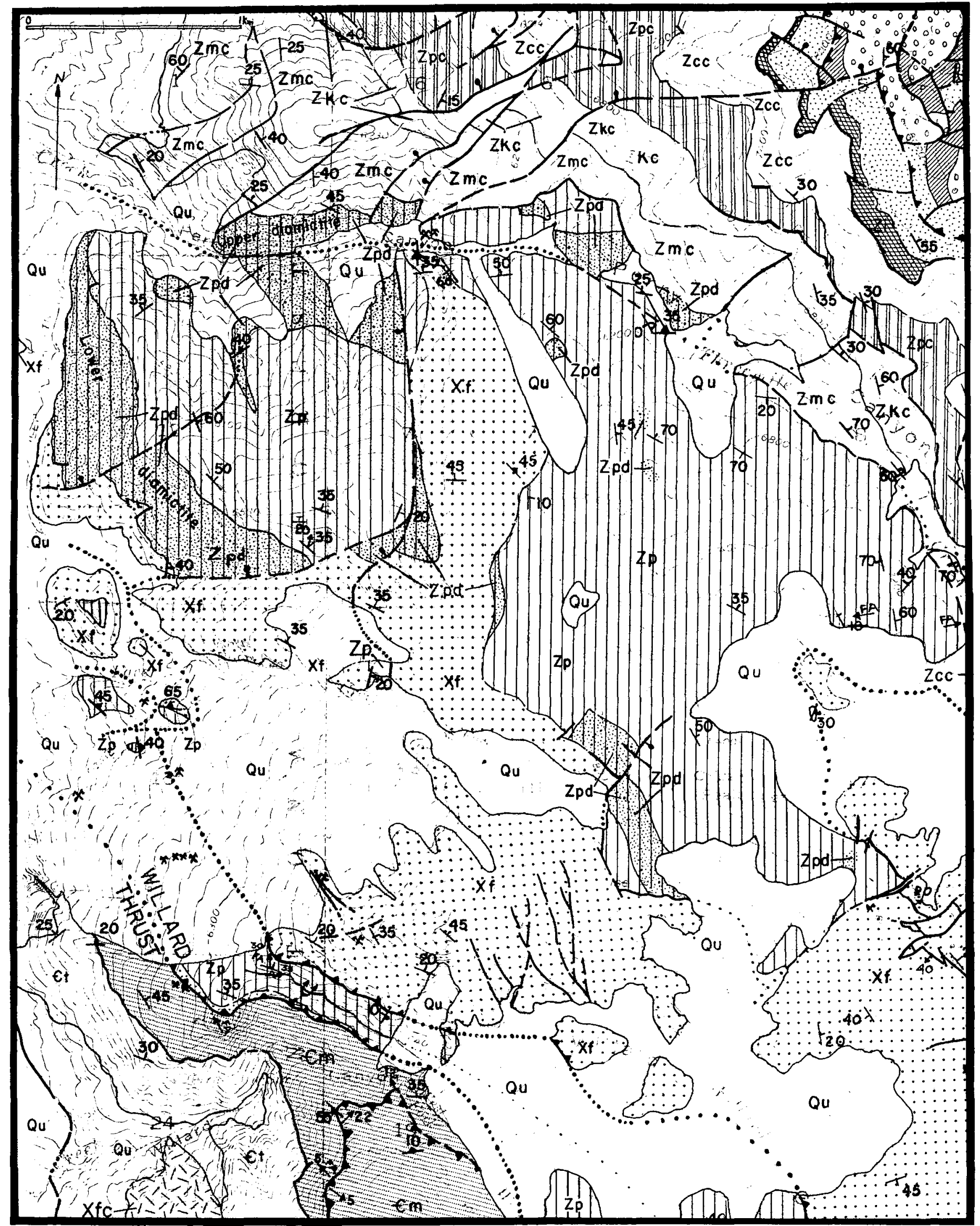

Figure 2. Map of area at mouth of Perry and Willard Canyons, showing lower and upper diamictite in the formation of Perry Canyon (after Sorensen and Crittenden, 1976). Locality shown in Figure 1. 


\section{FIGURE 2}

\section{EXPLANATION}

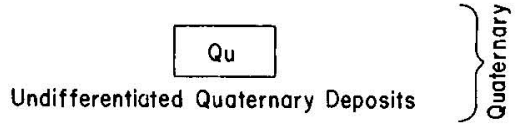

$\begin{array}{cl}\text { LOWER PLATE OF } & \text { UPPER PLATE OF } \\ \text { WILLARD THRUST } & \text { WILLARD THRUST }\end{array}$

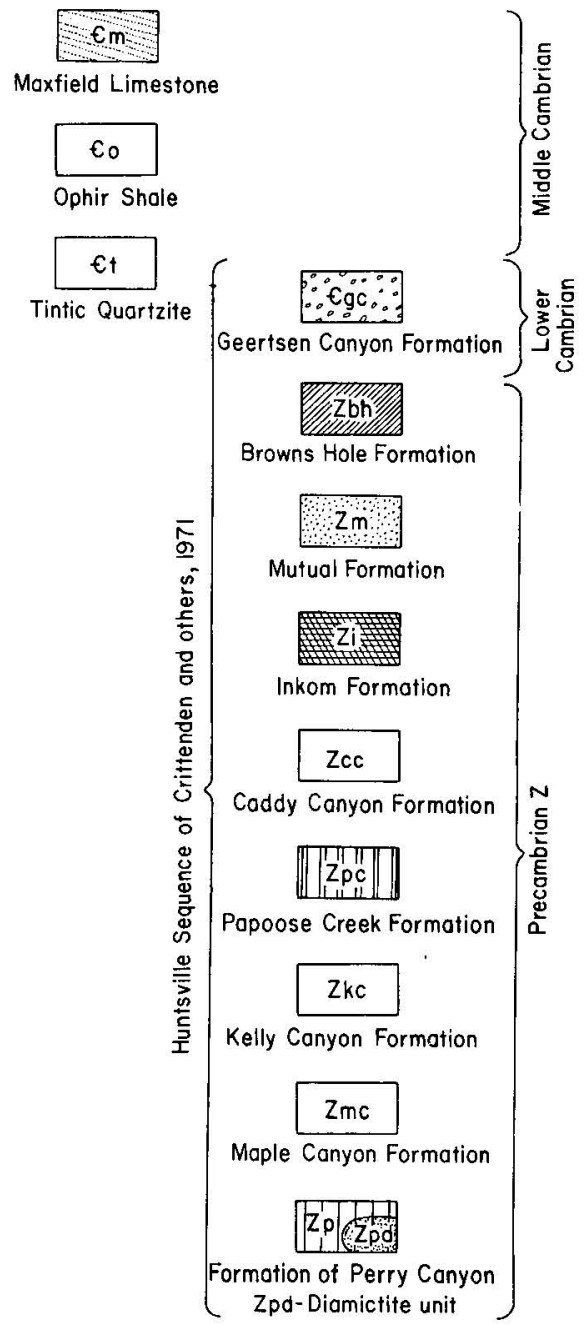

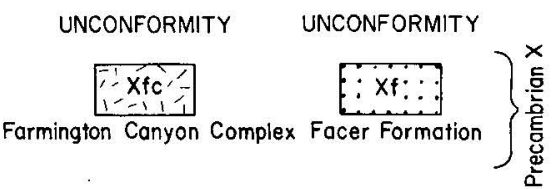

exposed on the wooded south slope of Perry Canyon, the medial unit appears from a cross section to be about $500 \mathrm{~m}$ thick.

The upper part of the formation of Perry Canyon consists of massive diamictite that forms prominent dark cliffs on the north slope of Perry Canyon about $1 \mathrm{~km}$ east of the mountain front. Although the base is cut by a fault in Perry Canyon and may actually be in a separate thrust sheet, this body of diamictite appears to overlie the medial unit of graywacke and siltstone and is overlain by laminated greenish-gray, finegrained siltstone assigned to the Maple Canyon Formation (Crittenden and others, 1971). About $200 \mathrm{~m}$ of diamictite is exposed in the cliffs, and an additional thickness of as much as $100 \mathrm{~m}$ is exposed on the south slope of the canyon. The total thickness is approximate because of the uncertain effects of the fault that has been mapped following the bottom of the stream canyon to the east. The rocks above and below the two diamictites, however, are quite different, and it is unlikely that they represent a single horizon repeated by faulting. A clast count in the upper diamictite recorded $70 \%$ granite and gneissic rocks, $27 \%$ quartzite, and about $3 \%$ other sedimentary and igneous rocks.

\section{Willard Canyon to Pineview Reservoir}

On the north rim of Willard Canyon, a short distance southwest of the exposures just described, the formation of Perry Canyon forms a second band of outcrops that extends almost continuously southeast to Pineview Reservoir about $5 \mathrm{~km}$ west of Huntsville (Fig. 1). These exposures are also allochthonous but are in a structurally lower plate of the Willard thrust.

In contrast to the section at the mouth of Perry Canyon, this section contains diamictite only in lenticular pods ranging from 20 or $30 \mathrm{~m}$ to perhaps $400 \mathrm{~m}$ thick (see columns 6 and 7 of Fig. 4 below). In general, this section shows more evidence of downslope movement of glacially derived sediment (sliding and sediment gravity flow). In addition, submarine volcanic rocks, including pillow basalt (Fig. 3), and shallow intrusive rocks are more abundant, and a 1- to 3-mthick bed of carbonate that consists of either gray laminated limestone or, more rarely, pinkish-tan laminated dolomite forms a "cap" over several of the diamictite lenses similar to those described by Williams (1979) in Australia. Such caps locally extend beyond the limits of the diamictite lens. Although nowhere do two lenses of diamictite appear one above another, as they do at the mouth of Perry Canyon, some lenses rest directly on the underlying Facer Formation or on the Willard thrust, whereas others are entirely surrounded by non-glacial(?) deposits. Where diamictite is absent, the basal bed usually is a coarse arkosic grit, rarely more than $1 \mathrm{~m}$ thick, consisting of angular to subrounded grains in a silty matrix. In many places, it is faulted out or obscured by float. Between exposures of diamictite, the formation consists of dark gray to black, thin-bedded pyritic siltstone intercalated with beds of graywacke, dark gray sandstone, or locally tanweathering quartzite. Pyrite is disseminated in many of these rocks as cubes as large as 1 $\mathrm{cm}$ across. To the southeast beyond North Odgen Pass (Fig. 4), lenses of diamictite are
Figure 3. Basaltic pillow from volcanic rocks intercalated with diamictite member of the formation of Perry Canyon, North Ogden Pass, Utah. Specimen is 14 cm long.

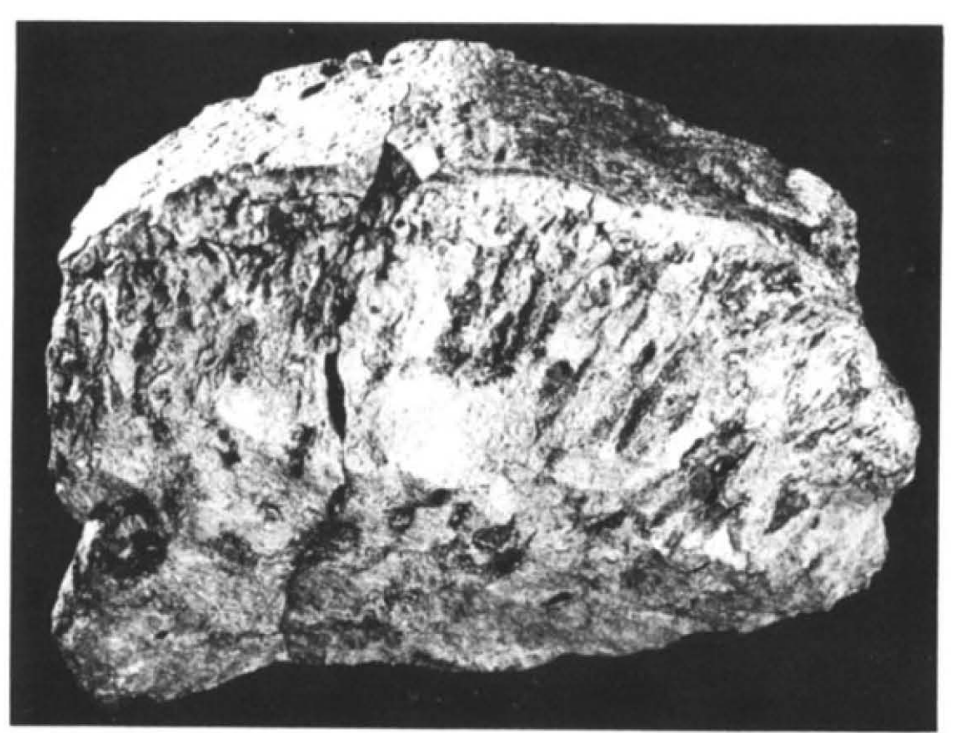




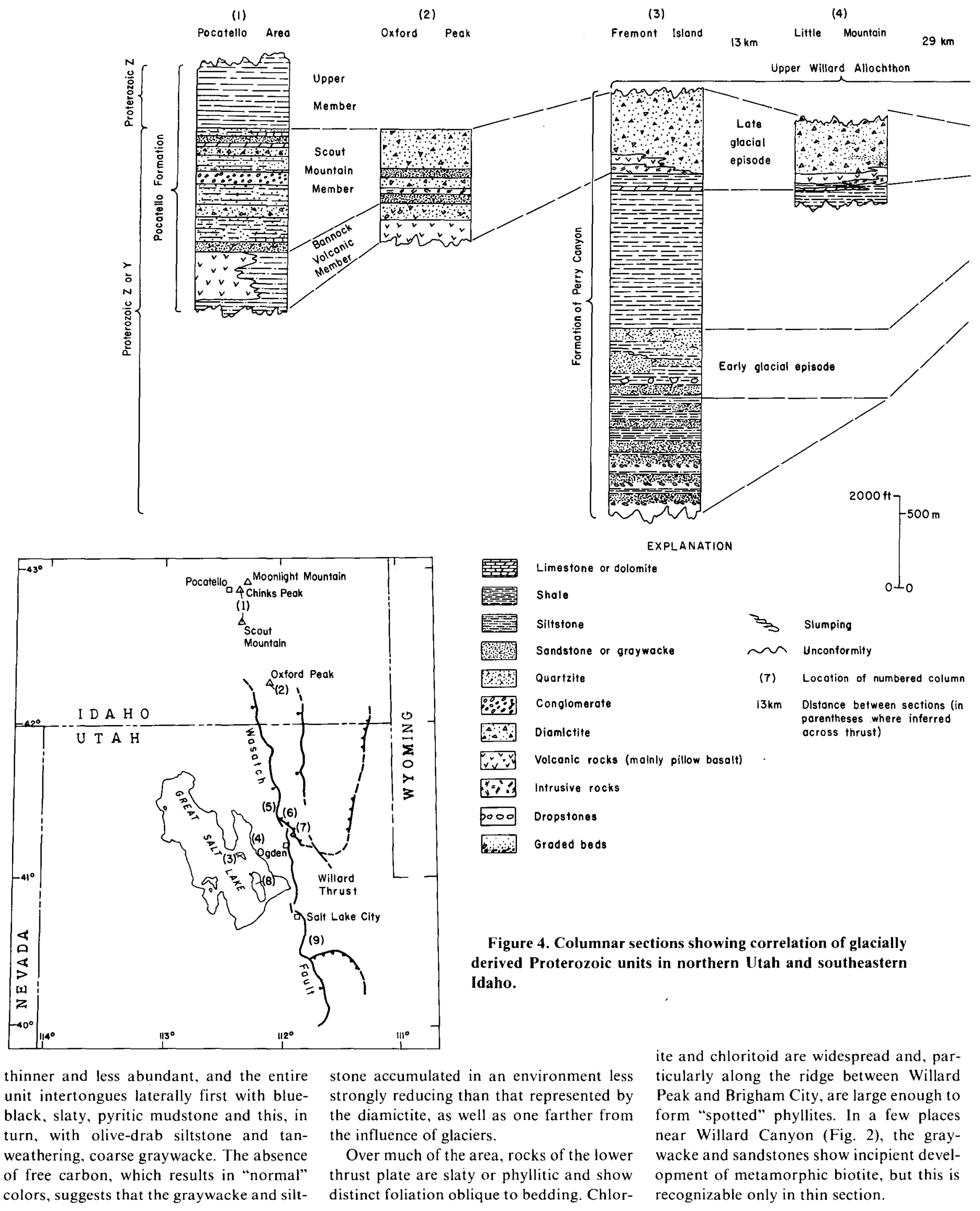




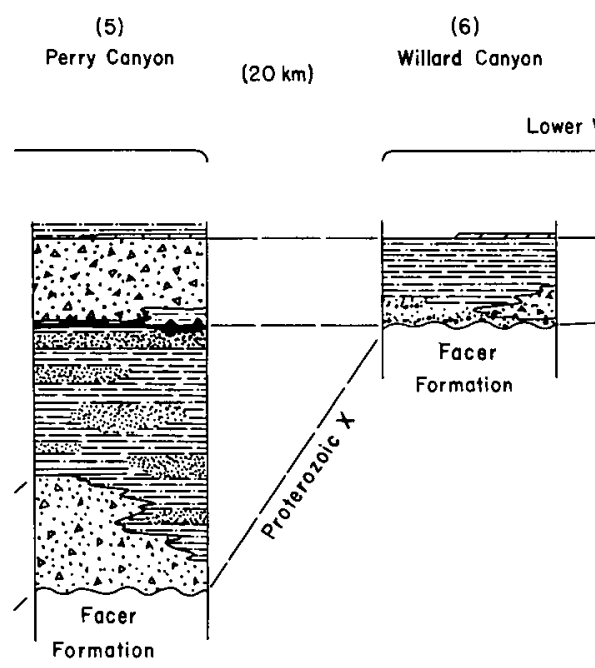

\section{Fremont Island}

At the west face of the Wasatch Range (Figs. 1 and 2), the Willard thrust is cut by the Wasatch fault and displaced southward, passing beneath the Great Salt Lake between Antelope and Fremont Islands (Crittenden, 1972). As a consequence, the westward extension of the allochthonous sequence exposed in Perry and Willard Canyons crops out on Little Mountain, Fremont Island, and nearby on the south end of Promontory Point. As noted above, the diamictite exposed only $10 \mathrm{~km}$ to the south on Antelope Island is structurally below the Willard thrust and therefore was deposited many tens of kilometres to the east of that in the allochthon.

The most distinctive unit of the rocks exposed on Fremont lsland is a 600-m-thick section of diamictite that extends across the northern ridge of the island and forms its highest point (Eardley and Hatch, 1940b; Condie, 1967; Blick, 1979). These and underlying rocks that occupy the remainder of the island are here assigned to the formation of Perry Canyon (Fig. 4, column 3). Near the western point of the island, the diamictite intertongues with basalt flows and peperite and is cut by several shallow sills. Although relict textures are well preserved, the igneous rocks are altered to greenstone that consists mainly of chlorite, sericite, epidote, actinolite, albite, calcite, and iron oxides. These rocks have been searched repeatedly for material fresh enough to use for isotopic dating, but without success. This diamictite is characterized by large clasts of gneissic granite (as much as $5 \mathrm{~m}$ ), many of which have been
(7)

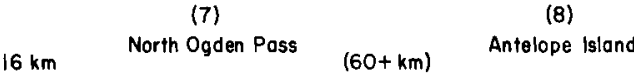

(9)

Minerol Fork 


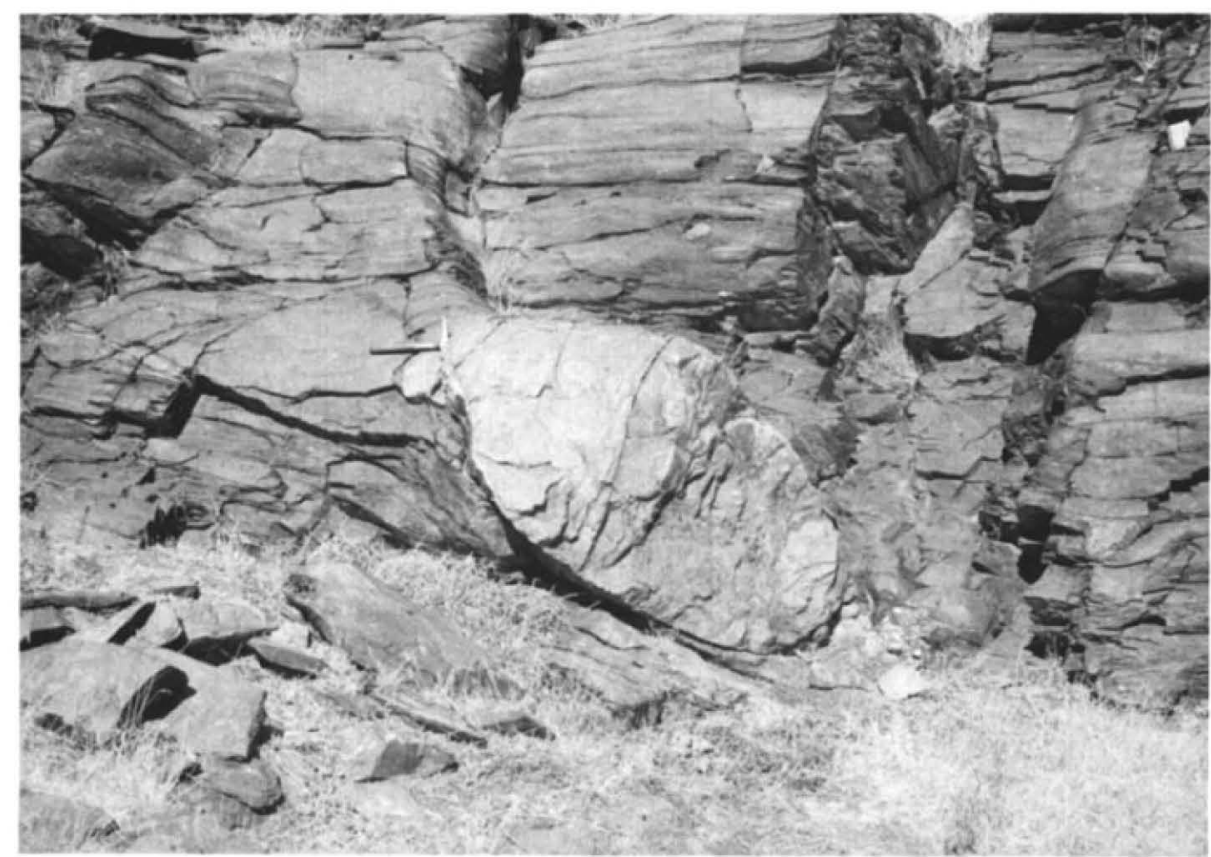

Figure 5. Dropstones, the largest $2.5 \mathrm{~m}$ long, enclosed in dark brown-weathering siltstone in lower glacial unit, Fremont Island.

shale originally designated the "lower member" by Trimble (1976) is actually part of the upper member. A revised stratigraphic column of the Pocatello Formation is shown in Figure 4 (column 1).

The Pocatello Formation is exposed along much of the length of the Bannock

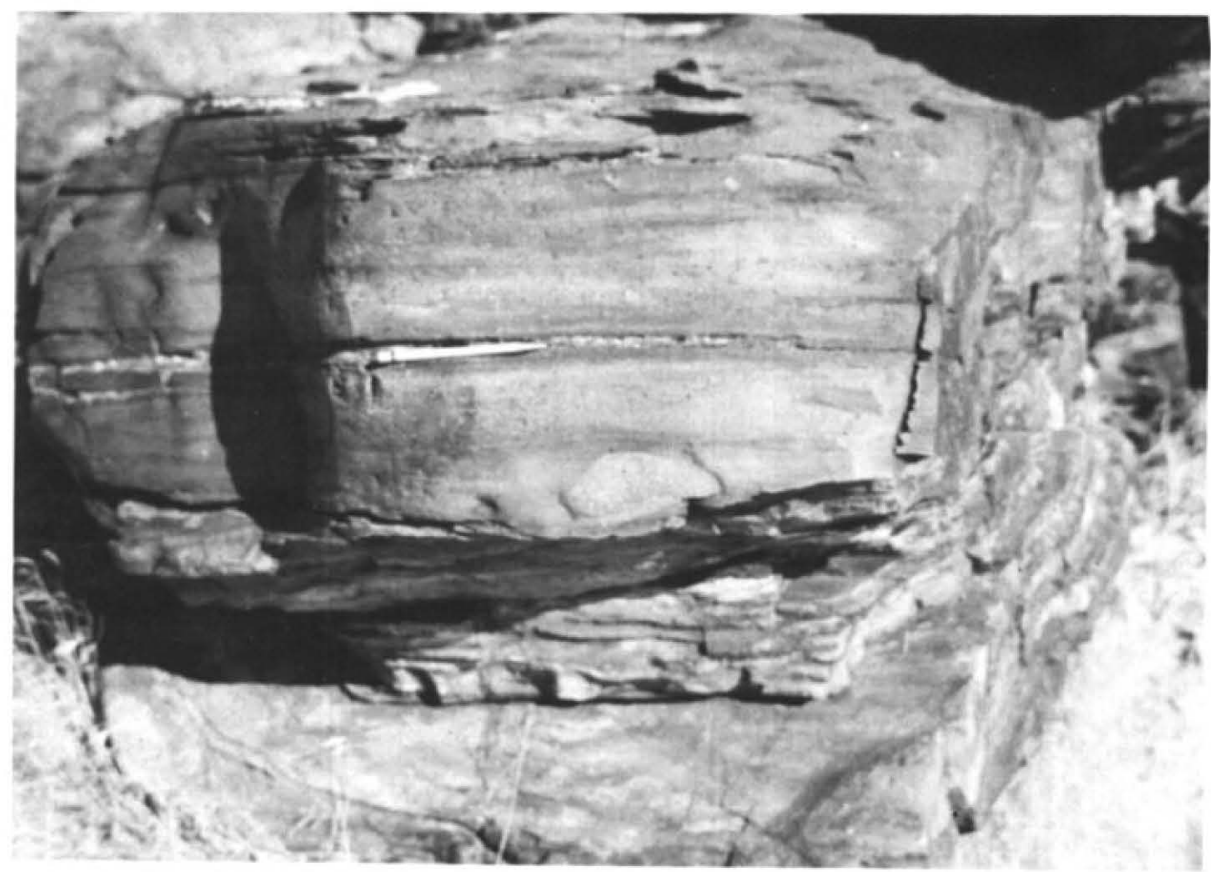

Figure 6. Sand clot $12 \mathrm{~cm}$ long, inferred to have been dropped into thinly laminated siltstone, lower glacial unit, Fremont Island. sparsely pebbly quartzite which, if unfaulted, is $280 \mathrm{~m}$ thick. A poorly exposed and lenticular interval of greenstone, breccia, and porphyritic lava assigned to the Bannock Volcanic Member overlies the quartzite. These volcanic rocks are $110 \mathrm{~m}$ thick on Scout Mountain and thicken northward. Next above them, there is a 70$m$ interval of brown, thin-bedded sandstone, followed by the lower diamictite, which is about $100 \mathrm{~m}$ thick. The lower diamictite is crudely bedded, and grades upward into inversely to normally bedded sandstone. Five pebble counts in this diamictite average $43 \%$ quartzite, $52 \%$ siltstone, and $5 \%$ volcanic rocks. A $150-\mathrm{m}$ coarsening-upward sequence of siltstone and graded sandstone overlies the lower diamictite, culminating in 50 to $100 \mathrm{~m}$ of cobble and boulder conglomerate that is intercalated with trough-cross-bedded medium- and coarse-grained sandstone. One pebble count in the conglomerate indicated $85 \%$ quartzite, $11 \%$ granitic rocks, $2 \%$ siltstone, and $2 \%$ volcanic clasts.

Quartzite and brown siltstone overlie the conglomerate and are in turn overlain by the upper diamictite, which is more than $150 \mathrm{~m}$ thick and contains clasts as much as $1.5 \mathrm{~m}$ in diameter. Striated clasts are present, although rare. Two pebble counts in the upper diamictite on Scout Mountain average $28 \%$ quartzite, $51 \%$ basement rock (granitic and gneissic rocks), 20\% siltstone, and $1 \%$ volcanic rock. A $1-m$-thick laterally persistent bed of laminated, pink silty dolomite caps the upper diamictite. The section above the upper diamictite is well exposed in structurally overturned beds north of Portneuf Narrows (Fig. 1), where a thinning- and fining-upward transgressive clastic and limestone sequence overlies the dolomite. The upper member of the Pocatello Formation is a monotonous dark gray, silver-weathering laminated and locally pyritic shale or argillite that is similar to the Kelley Canyon Formation of Utah and to postglacial shales (Twitya Formation) at a similar stratigraphic level in the Northwest Territories, Canada (Christie-Blick and others, 1980).

On the slopes west of Chinks Peak (Fig. 4) diamictite of the Scout Mountain Member is interbedded with and contains clasts of the Bannock Volcanic Member, which here reaches a thickness of $400 \mathrm{~m}$. Both diamictite and cobble conglomerate are present southeast of Chinks Peak and in an isolated northern exposure on Moonlight Mountain. The diamictite is thicker at these 
localities than on Scout Mountain, but structural complications preclude accurate measurement of the section.

The Scout Mountain Member near Pocatello consists of a variety of sedimentary facies (Link, 1982, 1983). The thickest diamictite is exposed in the north on Chinks Peak and Moonlight Mountain (Fig. 4), where it is interpreted as lodgement tillite or glaciomarine diamictite, in part deposited by sediment gravity flow. South of Portneuf Narrows, slope and basinal facies are present, including strata interpreted as turbidites and "contourites," mass-flow channelized conglomerate, and redeposited diamictite. The southernmost exposures at Garden Creek Gap (Fig. 1) consist predominantly of shallow-marine and nearshore deposits (Thompson and Link, 198I; Thompson, 1982).

\section{OXFORD PEAK, IDAHO}

At least $450 \mathrm{~m}$ of diamictite, graywacke, and siltstone of the Scout Mountain Member of the Pocatello Formation occurs on Oxford Peak (Fig. 1) and in isolated hills in Cache Valley to the east. These clastic rocks overlie and are intruded by mafic subaqueous volcanic rocks of the Bannock Volcanic Member of the Pocatello Formation that include pillow lava, agglomerate, volcaniclastic siltstone, and diabase sills. All are metamorphosed to greenschist facies.

The Scout Mountain Member is laterally variable, in both thickness and lithology. In its southernmost exposures at Five Mile Canyon, some $15 \mathrm{~km}$ southeast of Oxford Peak (Fig. 1), it contains $250 \mathrm{~m}$ of massive cobble-bearing diamictite. About 1 to $2 \mathrm{~km}$ south of Oxford Peak, it consists of $200 \mathrm{~m}$ of medium- to thick-bedded cobble diamictite, silt-chip diamictite, siltstone, and fine graywacke. These beds interfinger to the south with green volcaniclastic sandstone. Near Oxford Peak, a 40-m-thick sill of metadiabase intrudes silt-chip diamictite and extends about $10 \mathrm{~km}$ to the southeast. A generalized section is shown in column 2 of Figure 4.

Thirteen pebble counts in diamictite on Oxford Peak averaged $28 \%$ white, gray, and brown quartzite; $10 \%$ granite and vein quartz; $39 \%$ black and light gray siltstone; $10 \%$ medium and coarse sandstone; and $13 \%$ volcanic clasts, including white felsite and dark porphyry.

The massive diamictite at Five Mile Canyon is inferred to have been deposited as lodgement till near the grounding line of

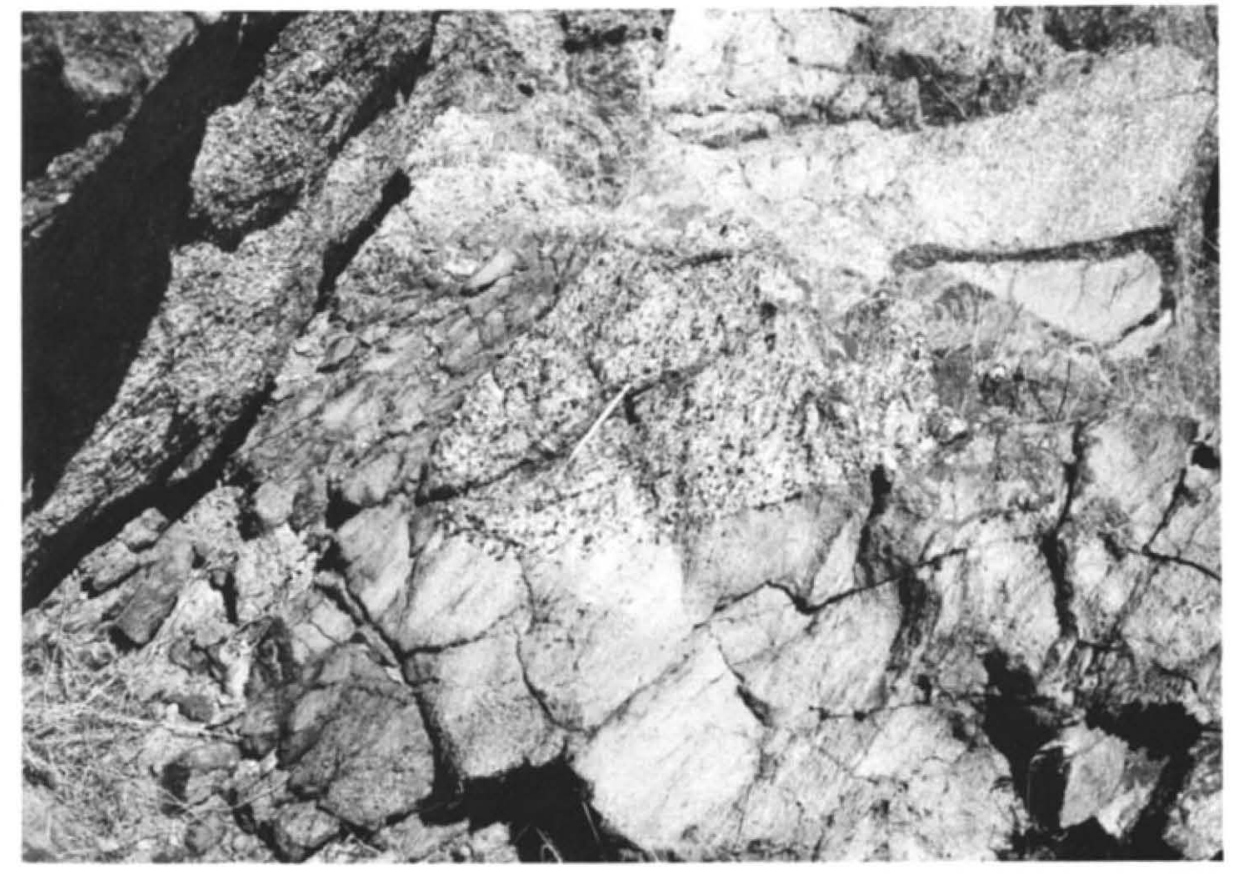

Figure 7. Folded coarse-grained graded beds below lowest glacial unit, Fremont Island. Pencil is $12 \mathrm{~cm}$ long.

an ice sheet that reached the sea. The heterogeneous beds along the ridge south of Oxford Peak are interpreted as diamicton deposited by sediment gravity flow and sediment derived by the winnowing of diamicton, intercalated with volcanic sand and pillow lava. A common and distinctive lithology is silt-chip diamictite with a small component of quartzite or granitic clasts. The silt fragments are thought to have been incorporated during redeposition of diamicton on a submarine slope.

\section{SHEEPROCK MOUNTAINS}

A thick sequence of little-metamorphosed, allochthonous Proterozoic rocks, including diamictite, occurs in the Sheeprock Mountains, about $135 \mathrm{~km}$ south of Fremont Island and $60 \mathrm{~km}$ west of the Wasatch Mountains (Figs. 1 and 8). Several major thrusts separate these rocks from those immediately above the Willard thrust, but it seems likely that the rocks of Sheeprock Mountains were transported about the same distance eastward with respect to the autochthon as was Fremont Island (Blick, 1979).

Proterozoic rocks were early recognized in the Sheeprock Mountains by Loughlin (1920) and the over-all stratigraphy was established in mapping by Cohenour (1959) and others in the 1950s. Subsequent mapping by Morris and Kopf (1970a, 1970b) and Christie-Blick (1982b) has led to further stratigraphic subdivision and recognition of individual formations of the Huntsville sequence of Crittenden and others (1971). Diamictite occurs in two stratigraphic units, the lower one in the middle of the Otts Canyon Formation and the upper one in the overlying Dutch Peak Formation (Dutch Peak "tillite" of Cohenour, 1959). The lower diamictite is thin and lenticular and is separated from the thick upper body by several hundred metres of quartzite. in the vicinity of Otts Canyon (Fig. 8, column 3), where it is from 0 to $500 \mathrm{~m}$ thick and consists of interbedded diamictite, graywacke, grit, quartzite, and slate. Underlying rocks consist of several hundred metres of gray and silver-gray, banded slate and phyllite, lithologically similar to pelitic rocks interbedded with the diamictite, and suggestive of a conformable and perhaps interfingering contact. The diamictite occurs in intervals from a few metres to several tens of metres thick and is generally in sharp contact with adjacent slate and quartzite. The diamictite matrix is gray, green, or black, and phyllitic; texturally, it is fairly homogeneous to heterogeneous with silty and gritty wisps. The concentration of
The lower diamictite unit is best exposed 
(1)

Block Crook Peak
(2)

Dutch Peak

$7 \mathrm{~km}$

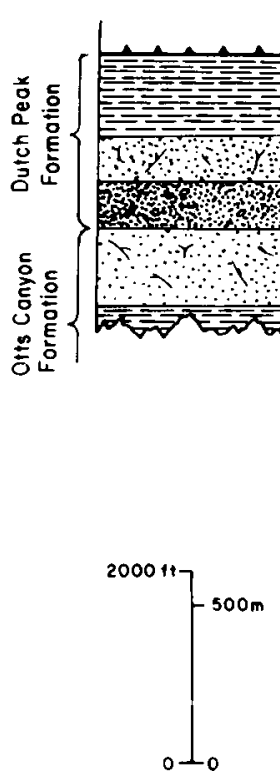

Figure 8. Columnar sections showing correlation of glacially derived Proterozoic units in the Sheeprock Mountains and Deep Creek Range, central and western Utah. Lithologic symbols as in Figure 4. Index map is for Sheeprock Mountains only. Deep Creek Range is located in area shown in Figure 1.

clasts is variable; typically these consist of about $95 \%$ quartzite, with subordinate quartz, dolomite, granite, and intraformational siltstone. Dolomite is locally abundant, however. Clasts are predominantly 2 to $5 \mathrm{~cm}$ in diameter, but a few are as large as boulders. Beneath the Pole Canyon thrust, in the vicinity of Otts Canyon, the lower diamictite unit thins abruptly toward the north. Above the Pole Canyon thrust, it is less than $70 \mathrm{~m}$ thick and pinches out toward the northwest. The lower diamictite is not exposed south of the Indian Springs tear fault (Fig. 8, column 4), probably because the exposures do not extend far enough downsection at this locality (Blick, 1979).

Between the diamictite units, and constituting the upper member of the Otts Canyon Formation (Fig. 8, column 3), there are several hundred to more than $1,000 \mathrm{~m}$ of gray quartzite, with subordinate interbeds of conglomerate and grit (especially near the base), and of graywacke, slate, siltstone, and shale (especially near the top). The
(3)

$(6 \mathrm{~km})$

Pole and Otts Canyons

$(5 \mathrm{~km})$
(4)

South She eprock

Mountoins
(5)

Deep Creek Ronge
Deep Creek Rom
$(125 \mathrm{~km}) \quad$ (Fig. 1) 
metallic blue-gray quartzite, associated with dropstones near the base of the Dutch Peak, persists along the northern flank of the Sheeprock Mountains for several kilometres at the same stratigraphic level. Angular diabase fragments, locally included in conglomerate above this marker bed, were probably derived from the underlying diabase sills or compositionally similar rocks at about the same stratigraphic level. The diabase fragments thus attest to local erosion (channels?) and to penecontemporaneous mafic volcanism as in other parts of the allochthon. Poorly sorted rocks of the Dutch Peak Formation are typically olive green to gray, chloritic, moderately phyllitic, and mineralogically, chemically, and texturally heterogeneous at microscopic to megascopic scales (Blick, 1979). Major clast types are dolomite, granite, and quartzite (including the rare but distinctive chromian variety). Subordinate types include a variety of metamorphic, igneous, and sedimentary rocks. In the Sheeprock area, 29 clast counts indicate pronounced lateral and stratigraphic variations in the proportions of clast types over short distances, but some gross generalizations can be made. Dolomite clasts are most abundant near the base and toward the east, quartzite clasts are most common near the top and south of the Indian Springs fault, and igneous clasts are particularly common in the northwest. Clasts are predominantly 2 to $5 \mathrm{~cm}$ in diameter, although rarely as large as $3 \mathrm{~m}$ (one granite gneiss and one chromian quartzite). Rocks above the Pole Canyon thrust are coarsest near the base. The size of largest clasts decreases stratigraphically upward and toward the south. Diamictite and conglomerate of the Dutch Peak Formation intertongue with lenticular, mature quartzite in the upper part and in southern exposures. In addition, thick, poorly sorted rocks pass laterally into rather thinner quartzite toward the northwest in the vicinity of Black Crook Peak (Fig. 8, columns 1 and 2).

The thinning of both diamictite units and the intervening quartzite toward the northwest and the facies change of the upper diamictite to quartzite in the same direction suggest deposition near the edge of a locally subsiding marine embayment. The diamictite is interpreted to be mainly a basinal deposit, and the quartzite to represent better-sorted shelf sand that prograded into the adjoining basin. The bedding characteristics and textural heterogeneity of the diamictite and the association at many strati- graphic levels of diamictite with laminites containing dropstones suggest that the diamictite was deposited by sediment gravity flow and from floating ice. Paleocurrents estimated from the few available structures in the upper diamictite and the medial quartzite are directed toward the southwest, perhaps approximately parallel to the edge of the inferred basin. The Sheeprock basin was characterized by generally oxidizing conditions and differs in this respect from the Perry Canyon and Mineral Fork basins, where conditions were reducing.

\section{DEEP CREEK RANGE}

Metadiamictite, presumably in the western part of the allochthon, crops out about $125 \mathrm{~km}$ west of the Sheeprock Mountains in the southern part of the Deep Creek Range in two units separated by about $200 \mathrm{~m}$ of quartzite (Misch and Hazzard, 1962). Bick (1966) reinterpreted the outcrop pattern in terms of a single diamictite unit repeated by a tight syncline, with a core of quartzite. Facing directions are difficult to determine from available sedimentary structures because the rocks are in the garnet and staurolite grades of regional metamorphism (Nelson, 1969) and have a strong schistose fabric. Nevertheless, important lithologic differences between the diamictite units seem to corroborate the original interpretation of Misch and Hazzard (1962). The lower unit consists of sparsely pebbly schist, which appears to be less sandy and gritty and better bedded than the generally more crowded pebbly diamictite of the upper unit (Christie-Blick, 1982b). Clasts, mostly the size of pebbles but rarely as large as $1 \mathrm{~m}$, are mainly "granite" (gneissose and directionless varieties; about $70 \%$ ) and quartzite (about 25\%). Subordinate types are other metamorphic, igneous, and sedimentary rocks, including marble. The interpretation of the diamictite units as glaciomarine (Misch and Hazzard, 1962) is tentatively reaffirmed on the basis of well-developed bedding and the presence of a possible dropstone near the top of the upper unit.

\section{CORRELATION OF GLACIAL DEPOSITS WITHIN UTAH}

Until recently, stratigraphic data have been inadequate to permit detailed correlation of glacial deposits between any of these sections of Proterozoic $Z$ age. Mapping described above, however, now suggests that the glacial episodes recorded by thick bodies of diamictite or by the presence of dropstones can be correlated confidently at least within northern and central Utah. The correlations currently proposed (Figs. 4 and 8 ) are based on stratigraphic position and on the presence of intercalated or closely associated volcanic rocks and, locally, of carbonate rocks. They are strongly supported also by unit-by-unit correlation of the overlying non-glacial formations that constitute the remainder of the Huntsville sequence (Crittenden and others, 1971; Christie-Blick, 1982b).

Correlation within the Willard allochthon is comparatively straightforward. The presence of intercalated pillow basalt and the distinctive underlying gray clastic dolomite permits a direct tie from the thick diamictite on Fremont Island to that exposed on Little Mountain (Christie-Blick, 1980b). From there to exposures in the Wasatch Range, the tie is less explicit, but in the upper allochthon at Perry Canyon, the upper diamictite also contains thick lenses of pillow basalt in exposures 1.5 to $2.5 \mathrm{~km}$ east of the canyon mouth, whereas igneous rocks are thin or absent in the lower diamictite. Correlation of the upper diamictite with diamictite in the lower Willard allochthon also is supported by pillow basalts and mafic to intermediate intrusives present in that unit, particularly near North Ogden Pass (Fig. 4, column 7). The formation of Perry Canyon as a whole thins eastward, and the upper diamictite horizon rests directly on the Willard thrust in the southeasternmost exposures in Ogden Canyon. This is to be expected from the observation that over a larger area the Willard thrust rises stratigraphically eastward.

Correlation of the glacial units within the allochthon from Perry Canyon and Fremont Island to the Sheeprock Mountains, $135 \mathrm{~km}$ to the south (Fig. 8), is much more difficult, even though all the major units of the Huntsville sequence of Crittenden and others (1971) except the Maple Canyon Formation can be recognized in both areas (Christie-Blick, 1982b). This difficulty is reflected in the use of different names (the Otts Canyon and Dutch Peak Formations) for the glacial units. The Kelley Canyon Formation, which overlies the Maple Canyon in the northern Wasatch Range, rests directly on the Dutch Peak in the Sheeprock Mountains. The greatest difference between the two sequences is that quartzite intervenes between the diamictite units in the Sheeprock Mountains, whereas graywacke and siltstone occupy this interval in 
Perry Canyon and slate does so on Fremont Island. In addition, the diamictites in the two areas are petrographically quite distinct. On the other hand, the lower glacial unit in both areas overlies other "basinal" deposits, and the upper unit in both is associated with mafic volcanic or intrusive rocks. These similarities suggest that the glacial units in the two areas may be correlative in spite of the differences between them.

Units of the Huntsville sequence have not been recognized in the Deep Creek Range, probably for the most part as a result of lateral facies changes, but also as a result of metamorphism and structural complications. Regardless of this problem, the tie from the Sheeprock Mountains westward to the Deep Creek Range is perhaps more secure than correlations to the north and east. In the Deep Creek area, diamictite units are separated by mature quartzite and overlain by schist that may be equivalent to the Kelley Canyon Formation (Fig. 8, column 5). Although the rocks differ in detail from those in the Sheeprock Mountains, the over-all sequence is very similar.

Correlation from the allochthon to the autochthon within Utah also remains problematic; the mafic igneous rocks, preferentially associated with the upper diamictite within the allochthon, are entirely absent in the autochthon. The capping layer of pinkish-tan, laminated dolomite in the autochthonous or parautochthonous section of diamictite on Antelope Island (Fig. 4, column 8 ), however, closely resembles the laminated dolomites that locally overlie the diamictites of Perry Canyon and the conglomerate beds of the Maple Canyon Formation. The closest exposure of such laminated dolomite in the allochthon is at the south tip of Promontory Point, where it appears to be associated with coarse, darkgray, granule-bearing quartzite assigned to the Maple Canyon Formation that may be a facies equivalent of diamictite. Unfortunately, the detailed stratigraphic relations of these units to the rocks on Fremont Island are obscured by the intervening arm of Great Salt Lake. The best current inference is that the diamictite on Antelope Island represents a thinner shoreward equivalent of the upper diamictite of the Fremont Island, Little Mountain, and Perry Canyon sections. Such a correlation would be consistent with a general west-dipping paleoslope beneath the diamictite, combined with onlap of basin deposits toward the east. Some support is offered also by clast lithology; gneissic granite predominates in both allochthonous and autochthonous deposits, and one of us (Crittenden) has observed that clasts of the distinctive green chromian quartzites are a characteristic although minor constituent in both sections. Palinspastic restoration of the Willard thrust, however, indicates that the sections now exposed in Perry and Willard Canyons were originally deposited somewhere northwest of the present site of Antelope Island. Therefore, because the upper diamictite thins and becomes lenticular southeastward in the allochthon, the diamictites on Antelope Island may never have been directly continuous with those in the allochthon.

The Mineral Fork Tillite in the Cottonwood area (Fig. 4, column 9) lies nearly 30 $\mathrm{km}$ farther southeast and contains still fewer clues as to possible correlation. Neither basic volcanic rocks nor persistent bedded carbonate rocks are present. Moreover, clast composition is dominated by quartzite and dolomite, suggesting derivation from a sedimentary terrane, rather than one dominated by gneiss and granite. Although carbonate rocks are entirely absent from the underlying Big Cottonwood Formation and from the correlative Uinta Mountain Group that lies to the east along the trend of the subglacial valleys in which the Mineral Fork was deposited, it seems most likely that the abundant carbonate clasts in the Mineral Fork, which include oolitic and stromatolitic dolomites, were derived from a stratigraphically higher part of one or the other of those sequences of Proterozoic $Y$ age. Such carbonate rocks are inferred to have been removed from the Uinta Mountain area by erosion during late Proterozoic glaciation or prior to deposition of the Cambrian and Mississippian rocks that now overlie the rocks of the Uinta Mountain Group in the western part of the range.

\section{CORRELATION FROM NORTHERN UTAH TO SOUTHEASTERN IDAHO}

Intercalated diamictite and mafic volcanic and shallow intrusive rocks assigned to the Pocatello Formation and exposed near Oxford Peak (Fig. 4, column 2) are correlated with the upper diamictite of the formation of Perry Canyon in the Willard allochthon. The outcrops of pillow basalt, volcaniclastic siltstone, and massive diamictite on Oxford Peak and near Twin Lakes Reservoir in Cache Valley to the east are strikingly similar to the exposures on Little Mountain near Ogden. Near Pocatello (Fig. 4, column 1), two thin units of diamic- tite are present in the Pocatello Formation, but they occupy a very restricted stratigraphic range and locally intertongue with the volcanics. Where both diamictites are present, they overlie the main mass of volcanic rocks. Therefore, the diamictites near Pocatello are also thought to correlate with only the younger of the two episodes of glaciation represented in the formation of Perry Canyon in Utah.

\section{REGIONAL CORRELATION}

The general equivalence of glacial rocks of late Proterozoic age throughout the Cordillera is now widely accepted (Stewart, 1972; Christie-Blick and others, 1980), but in most areas, only one episode of glaciation has been recognized. In view of the evidence presented here for two such episodes in parts of Utah, a similar possibility needs to be examined for other areas.

In the Death Valley area of California, thick bodies of diamictite in the upper Proterozoic Kingston Peak Formation were recognized long ago by Hazzard (1937), and it seems likely that these units are generally correlative with the glacial deposits in Utah and Idaho described above. Nevertheless, although these bodies locally reach nearly $3,000 \mathrm{~m}$ in thickness, and in places record fluctuations of an ice margin (Miller, 1982), detailed stratigraphic and paleogeographic studies completed to date do not yield evidence for more than one widespread episode of glaciation (Wright and others, 1976; Miller and others, 1981).

The southeastern part of the Mackenzie Mountains of the Northwest Territories, Canada, is the only other area where upper Proterozoic strata may record two episodes of glaciation. Eisbacher (1978) showed that locally, north of the Redstone River, 15 to $20 \mathrm{~m}$ of diamictite occurs at the base of the Sayunei Formation, and it is separated from the massive diamictites of the overlying Shezal Formation by about $250 \mathrm{~m}$ of maroon siltstone (see section 7 of his Fig. 10). This thickness is approximately comparable with that separating the diamictite units in Utah, suggesting that two pulses of glaciation may be represented here also. However, both Young (1976) and G. H. Eisbacher (1980, written commun.) noted that the siltstones grade laterally into turbidites containing abundant outsized clasts believed to be dropstones. Thus, over a larger area, glaciation may have been relatively continuous, and there is no firm basis for detailed correlation with the two glacial intervals described in Utah. 


\section{PALEOGEOGRAPHIC SETTING AND SEDIMENTATION RATE}

The data now available suggest that early in Proterozoic $Z$ time, the present site of central Utah and adjoining parts of western North America were situated within a continent that was undergoing regional extension and glaciation. Glacial deposits occur intermittently throughout the Cordillera from Death Valley to Alaska (Stewart, 1972; Christie-Blick and others, 1980). Tongues of ice periodically extended into the adjoining sea and dropped their entrained debris on the edge of the continental platform, and in graben where it mingled with normal marine sediments. Glacial deposits that may be similar in age are present in the southern Appalachian Mountains (Schwab, 1976; Rankin and others, 1969), but because no traces of late Proterozoic glaciation are preserved in the central part of North America, the possible extent of ice sheets across the craton cannot be determined.

The best-documented lithologic analogues for these Proterozoic deposits are from the Antarctic (Barrett, 1975; Anderson and others, 1981) and the Miocene through Holocene deposits of the Yakataga Formation off the coast of Alaska (Plafker and Addicott, 1976). Although the latter are inferred to be the product of alpine glaciation along a rugged coastline rather than a low-lying one, the sediments bear a close resemblance to those of the formation of Perry Canyon and the Mineral Fork Tillite. Diamictite is abundant in all sections of the Yakataga, locally making up more than $60 \%$ of the formation. Siltstone and mudstone vary greatly in abundance, as in Utah. However, sandstone and conglomerate (outwash?) appear to be more common in the Yakataga than in the Perry Canyon, and in this respect, the Yakataga more closely resembles the Mineral Fork Tillite.

Although sediment accumulation rates are notoriously variable (Sadler. 1981), the time interval that separated the late Proterozoic glacial episodes proposed in this paper can be evaluated if appropriate rates are assumed. Barrett (1975) estimated an average accumulation rate of $40 \mathrm{~m} / \mathrm{m}$.y. for several hundred metres of silty claystone with sparse pebbles in the Ross Sea. Plafker and Addicott (1976) calculated a considerably higher sedimentation rate of about 1,000 $\mathrm{m} / \mathrm{m}$.y. for nearly $1,200 \mathrm{~m}$ of Pleistocene diamictite and conglomerate on the outer continental shelf of the Gulf of Alaska. If these rates are applicable to the formation of Perry Canyon, the glacial episodes may have been separated by as little as $0.5 \mathrm{~m} . \mathrm{y}$. or as much as $25 \mathrm{~m} . \mathrm{y}$.

\section{ACKNOWLEDGMENTS}

The data reported here are by-products of geologic mapping by the U.S. Geological Survey (Crittenden and associates in Utah and S. S. Oriel and associates in Idaho) beginning as early as 1950 and continuing intermittently through 1981 . This research included detailed mapping in the central and northern Wasatch Range and reconnaissance on Antelope and Fremont Islands in the Great Salt Lake. Recent geologic mapping and sedimentologic studies by Christie-Blick in the Wasatch Range, on Fremont Island, at Little Mountain, and in the Sheeprock Mountains, and by Link in southeastern Idaho were supported by $\mathrm{Na}$ tional Science Foundation Grants ATM 7424201, EAR 77-06008, and EAR 78-15194 to J. C. Crowell. Responsibility for this report is shared jointly, except for the parts dealing with the Sheeprock Mountains and Deep Creek Range, Utah, prepared by Christie-Blick, and the section on southeastern Idaho, prepared by Link. We are indebted to H. Doelling, J.M.G. Miller, H. T. Morris, and L. A. Woodward for helpful reviews of the manuscript.

\section{REFERENCES CITED}

Anderson, J. B., Kurtz, D. D., Domack, E. W. and Balshaw, K. M., 1981, Antarctic glacial marine sediments: Journal of Geology, v. 88 , p. 399-414.

Barrett, P. J., 1975. Textural characteristics of Cenozoic preglacial and glacial sediments at site 270, Ross Sea, Antarctica, in Hayes, D. E., Frakes, L. A., and others, Initial reports of the Deep Sea Drilling Project. Volume 28: Washington, D.C., U.S. Government Printing Office, p. 757-767.

Bick, K. F., 1966, Geology of the Deep Creek Mountains, Tooele and Juab Counties, Utah: Utah Geological and Mineralogica! Survey Bulletin 77, $120 \mathrm{p}$.

Blackwelder, E., 1910, New light on the geology of the Wasatch Mountains, Utah: Geological Society of America Bulletin, v. 21, p. $517-542$.

- 1925, Wasatch Mountains revisited [abs.]: Geological Society of America Bulletin, v. 36, p. 132-133.

- 1932, An ancient glacial formation in Utah: Journal of Geology, v. 40, p. 289-304.

Blick, N. H., 1979, Stratigraphic, structural and paleogeographic interpretation of upper Proterozoic glaciogenic rocks in the Sevier orogenic belt, northwestern Utah [Ph.D. dissert.]: Santa Barbara, California, University of California, $633 \mathrm{p}$.

Boulton, G. S., and Deynoux, M., 1981, Sedimentation in glacial environments and the identification of tills and tillites in ancient sedimentary sequences: Precambrian Research, v. 15, p. 397-422.

Bryant, B., 1980, Metamorphic and structural history of the Farmington Canyon complex, Wasatch Mountains, Utah [abs.]: Geological Society of America Abstracts with Programs, v. 12, p. 269.

Bryant, B., and Graff, P., 1980, lgneous rocks on Antelope Island, Great Salt Lake, Utah: Geological Society of America Abstracts with Programs, v. 12, p. 269.

Calkins, F. C., and Butler, B. S., 1943, Geology and ore deposits of the Cottonwood-American Fork area, Utah: U.S. Geological Survey Professional Paper 201, 152 p.

Christie-Blick, N., 1980a, Glacial advance and retreat sequences, upper Proterozoic Mineral Fork Formation, northwestern Utah: Geological Society of America Abstracts with Programs, v. 12, p. 269.

- 1980b, Field guide to the geology of Little Mountain, in Precambrian rocks of the northern Wasatch: Field trip number 6, Ogden, Utah, Geological Society of America Rocky Mountain Section Meeting, 8 p.

- 1982a, Upper Precambrian (Eocambrian) Mineral Fork Tillite of Utah: A continental glacial and glaciomarine sequence: Discussion: Geological Society of America Bulletin, v. 93, p. 184-186.

- 1982b, Upper Proterozoic and Lower Cambrian rocks of the Sheeprock Mountains, Utah: Regional correlation and significance: Geological Society of America Bulletin, v. 93, p. 735-750.

Christie-Blick, N., Link, P. K., Miller, J.M.G., Young, G. M., and Crowell, J. C., 1980, Regional geologic events inferred from upper Proterozoic rocks of the North American Cordillera: Geological Society of America Abstracts with Programs. v. 12, p. 402.

Cohenour, R. E., 1959, Sheeprock Mountains, Tooele and Juab Counties: Precambrian and Paleozoic stratigraphy, igneous rocks, structure, geomorphology, and economic geology: Utah Geological and Mineralogical Survey Bulletin 63, $201 \mathrm{p}$.

Condie, K. C., 1967, Petrology of the late Precambrian tillite(?) association in northern Utah: Geological Society of America Bulletin, v. 78, p. 1317-1343.

Crittenden, M. D., Jr., 1961, Magnitude of thrust faulting in northern Utah: U.S. Geological Survey Professional Paper 424-D, p. $128-131$.

- 1972, Willard thrust and the Cache allochthon. Utah: Geological Society of America Bulletin, v. 83, p. 2871-2880.

Crittenden, M. D., Sharp, B. J., and Calkins, F. C., 1952, Geology of the Wasatch Mountains east of Salt Lake City, Parleys Canyon to Traverse Range, in Marsell, R. E., ed., Geology of the central Wasatch Mountains: Utah Geological and Mineralogical Survey, Guidebook to the geology of Utah, no. 8, p. 1-37.

Crittenden, M. D., Jr., Schaeffer, F. E., Trimble, D. E., and Woodward, L. E., 1971, Nomenclature and correlation of some upper Precambrian and basal Cambrian sequences in western Utah and southeastern Idaho: Geological Society of America Bulletin, v. 82, p. $581-602$. 
Crittenden, M. D.. Stewart, J. H., and Wallace, C. A., 1972, Regional correlation of upper Precambrian strata in western North America; International Geological Congress, $24 \mathrm{th}$, Report, sec. I. p. 334-341.

Eardley, A. J., and Hatch, R. A., 1940a. Pre-Cambrian crystalline rocks of northcentral Utah: Journal of Geology, v. 48, p. $58-72$.

1940b. Proterozoic(?) rocks in Utah: Geological Society of America Bulletin, v. 51. p. 795-843.

Eisbacher, G. H., 1978, Re-definition and subdivision of the Rapitan Group. Mackenzie Mountains: Geological Survey of Canada Paper 77-35, $21 \mathrm{p}$.

Hazzard, J. C. 1937. Paleozoic section in the Nopah and Resting Springs Mountains, Inyo County. California: California Journal of Mines and Geology, v. 33, p. 273-339

Hedge, C. E. Stacey, J. S., and Bryant, B., 1983. Geochronology of the Farmington Canyon Complex. Wasatch Mountains, Utah, in Miller. D. M., Todd. V. R., and Howard K. A.. eds., Tectonic and stratigraphic studies in the eastern Great Basin: Geological Society of America Memoir 157 (in press).

Hintze. F. F.. Jr.. 1913, A contribution to the geology of the Wasatch Mountains, Utah: New York Academy of Sciences Annals, v. 23, p. 85-143.

King. P. B. 1969. The tectonics of North America A discussion to accompany the tectonic map of North America, scale 1:5.000,000: U.S. Geological Survey Professional Paper 628, $94 \mathrm{p}$

Knoll. A. H.. Blick, N.. and Awramik. S. M. 1981. Stratigraphic and ecologic implications of late Precambrian microfossils from Utah: American Journal of Science, v. 281 . p. $247-263$.

Larsen. W. N., 1957, Petrology and structure of Antelope Island, Davis County, Utah [Ph.D. dissert.]: Salt Lake City. Utah. University of Utah, $142 p$

Link, P. K.. 1981, Upper Proterozoic diamictites in southeastern Idaho, U.S.A., in Hambrey, M. J., and Harland, W. B., eds., Earth's pre-Pleistocene glacial record: Cambridge, England, Cambridge University Press, p. 736-739.

1982. Geology of the upper Proterozoic Pocatello Formation. Bannock Range. southeastern Idaho [Ph.D. dissert.]: Santa Barbara. California, University of California, $131 \mathrm{p}$

1983. Glacial and tectonically influenced sedimentation in the upper Proterozoic Pocatello Formation. southeastern Idaho. in Miller, D. M., Todd, V. R., and Howard. K. A.. eds., Tectonic and stratigraphic studies in the eastern Great Basin: Geological Society of America Memoir 157 (in press).

Link. P. K.. Bright, R. C., and Trimble. D. E.. 1980. New discoveries in the upper Proterozoic stratigraphy of southeastern Idaho: Geological Society of America Abstracts with Programs, v. 12. p. 278

Loughlin. G. F.. 1920, Sheeprock Mountains, in Butler, B. S., Loughlin, G. F., Heikes. V. C.. and others, The ore deposits of Utah: U.S. Geological Survey Professional Paper 111. p. $423-444$
Ludlum, J. C., 1942, Pre-Cambrian Formations at Pocatello, Idaho: Journal of Geology, v. 50, p. 85-95.

Miller, J.M.G., 1982, Kingston Peak Formation in the southern Panamint Range: $A$ glacial interpretation, in Cooper, J. D., Troxel. B. W., and Wright, L. A.. Geology of selected areas in the San Bernardino Mountains, western Mojave Desert, and southern Great Basin, California: Field trip number 9 , Anaheim, California, Geological Society of America Cordilleran Section Meeting, p. 155-164.

Miller, J.M.G.. Wright, L. A., and Troxel, B. W.. 1981. The late Precambrian Kingston Peak Formation, Death Valley region, California, in Hambrey, M. J., and Harland, W. B., eds., Earth's pre-Pleistocene glacial record: Cambridge, England, Cambridge University Press, p. 745-748.

Misch, P., and Hazzard, J. C., 1962, Stratigraphy and metamorphism of late Precambrian rocks in central northeastern Nevada and adjacent Utah: American Association of Petroleum Geologists Bulletin, v. 46, no. 3. p. $289-343$

Morris, H. T., and Kopf, R. W., 1970a, Preliminary geologic map and cross section of the Cherry Creek quadrangle and adjacent part of the Dutch Peak quadrangle. Juab County, Utah: U.S. Geological Survey, Open-File Map, scale 1:24,000.

1970b. Preliminary geologic map and cross section of the Maple Peak and adjacent part of the Sabie Mountain quadrangle, Juab County, Utah: U.S. Geological Survey Open-Fïle Map, scale 1:24,000.

Nelson. R. B., 1969. Relation and history of structures in a sedimentary succession with deeper metamorphic structures, eastern Great Basin: American Association of Petroleum Geologists Bulletin, v. 53, p. 307-339.

Ojakangas, R. W., and Matsch, C. L., 1980, Upper Precambrian (Eocambrian) Mineral Fork Tillite of Utah: A continental glacia and glaciomarine sequence: Geological Society of America Bulletin, Part I, v. 91 , p. 495-501.

1982, Upper Precambrian (Eocambrian) Mineral Fork Tillite of Utah: A continental glacial and glaciomarine sequence: Reply: Gcological Society of America Bulletin. v. 93. p. 186-187.

Ovenshine, A. T., 1970, Observations of iceberg rafting in Glacier Bay, Alaska, and the identification of ancient ice-rafted deposits: Geological Society of America Bulletin. v. 81. p. 891-894.

Plafker. G., and Addicott. W. O.. 1976. Glaciomarine deposits of Miocene through Holocene age in the Yakataga Formation along the Gulf of Alaska margin, in Miller. T. P., ed.. Recent and ancient sedimentary environments in Alaska: Anchorage. Alaska Geological Society, p. 1-23.

Rankin, D. W. Stern. T. W., Reed. J. C., Jr., and Newell, M. F., 1969, Zircon ages of felsic rocks in the upper Precambrian of the Blue Ridge. Appalachian Mountains: Science. v. 166. p. 741-744.

Royse, F.. Jr.. Warner, M. A., and Reese, D. L. 1975. Thrust belt structural geometry and related stratigraphic problems. WyomingIdaho-northern Utah, in Bolyard, D. W.. ed.. Deep drilling frontiers of the central Rocky Mountains: Rocky Mountain Association of Geologists, Symposium, p. 41-54.

Sadler, P. M., 1981, Sediment accumulation rates and the completeness of stratigraphic sections: Journal of Geology, v. 89, p. 569-584.

Schermerhorn, L.J.G., 1974, Late Precambrian mixtites: Glacial and / or non-glacial?: American Journal of Science, v. 274, p. 673-824.

Schwab. F. C., 1976, Depositional environments, provenance. and tectonic framework: Upper part of the late Precambrian Mount Rogers Formation, Blue Ridge province, southwestern Virginia: Journal of Sedimentary Petrology, v. 46, p. 3-13.

Sorensen, M. L., and Crittenden, M. D., Jr.. 1976, Preliminary geologic map of the Mantua Quadrangle and part of the Willard Quadrangle, Box Elder, Weber, and Cache Counties, Utah: U.S. Geological Survey, Miscellaneous Field Studies Map MF-720, scale $1: 24,000$

Stewart. J. H.. 1972. Initial deposits in the Cordilleran geosyncline: Evidence of a late Precambrian ( 850 m.y.) continental separation: Geological Society of America Bulletin, v. 83 , p. $1345-1360$

Stokes, W. L., 1963, compiler. Geologic map of northwestern Utah: Utah Geological and Mineralogical Survey, scale 1:250,000.

Thompson, B. J., 1982, The geology of the upper Proterozoic Scout Mountain Member. Pocatello Formation, Garden Creek Gap. Bannock Range, southeastern ldaho [M.S. thesis]: Pocatello, Idaho, Idaho State University, $41 p$

Thompson, B. J., and Link, P. K.. 1981. Stratigraphy of upper Proterozoic Pocatello Formation. Garden Creek Gap. Bannock County, Idaho: Geological Society of America Abstracts with Programs, v. 13, p. 228.

Trimble, D. E., 1976, Geology of the Michaud and Pocatelto quadrangles. Bannock and Power Counties, Idaho: U.S. Gcological Survey Bulletin 1400, 88 p.

Varney, P. J., 1976, Depositional environment of the Mineral Fork Formation (Precambrian), Wasatch Mountains, Utah. in Hill, J. G., ed.. Geology of the Cordilleran hinge-line: Rocky Mountain Association of Geologists, Symposium, p. 91-102.

Williams, G. E., 1979. Sedimentology, stable isotope geochemistry, and palaeoenvironment of dolostones capping late Precambrian glacial sequences in Australia: Journal of the Geological Society of Australia, v. 26. p. 377-386.

Wright. L. A., Troxel. B. W.. Williams, E. G. Roberts. R. T.. and Diehl, P. E.. 1976. Precambrian sedimentary environments of the Death Valley region, eastern California, in Troxel, B. W., and Wright, L.. A., eds., Geologic features, Death Valley: California California Division of Mines and Geology Special Report 106, p. 7-15.

Young. G. M.. 1976. Iron-formation and glaciogenic rocks of the Rapitan Group. Northwest Territories. Canada: Precambrian Research, v. 3, p. 137-158.

MaNis RIPT RE(GA'E!) BY THE SOC IETS Nonevarer 9.1981

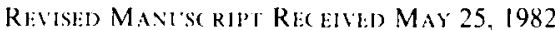

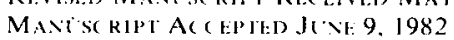

